\title{
The Disqualification of Dual Citizens from Parliament: Three Problems and a Solution
}

\author{
Harry Hobbs, Sangeetha Pillai and George Williams
}

\begin{abstract}
Since August 2017, the rule in s 44(i) of the Australian Constitution that dual citizens are incapable of being chosen for or sitting in federal Parliament has underpinned the disqualification or resignation of 10 parliamentarians. This disruption shows no signs of abating, with forthcoming cases, and outstanding questions about several sitting members. In this article, we outline three key problems with s 44(i), as well as a durable solution.
\end{abstract}

\section{Introduction}

Of the 226 members of the federal parliament elected in 2016, it has been suggested that around 10 per cent may be ineligible to hold their seats. This remarkable suggestion is due to the impact of s 44(i) of the Australian Constitution, which disqualifies dual citizens from being chosen for or sitting in the federal Parliament.

Over the past several months, s 44(i) has wreaked political havoc in the Commonwealth Parliament. Since August 2017, 10 parliamentarians have either resigned or been found ineligible to sit by the High Court ${ }^{1}$ two have had their eligibility confirmed by the Court; ${ }^{2}$ and serious questions have been asked over up to 12 further parliamentarians. The situation has been varyingly described as a 'constitutional crisis', ${ }^{3}$ a 'citizenship cyclone raging through Canberra' ${ }^{4}$ and a 'gigantic constitutional inconvenience'.

Crisis or not, the chaos that has stemmed from s 44(i) is in many ways absurd. While s 44(i) seeks to ensure that federal parliamentarians hold allegiance and undivided loyalty to Australia, ${ }^{6}$ the recently disqualified parliamentarians did not seek, and in many cases did not know, that they held foreign citizenship. There is no suggestion that any were involved in disloyal conduct or any other wrongdoing. In a nation in which half the population is born or has a parent born overseas, it is worth questioning whether s 44(i) of the Constitution should render people unfit for political service simply because another country recognises them as a citizen.

\footnotetext{
${ }^{1}$ Re Canavan (2017) 91 ALJR 1209; Re Nash [No 2] [2017] HCA 52.

${ }^{2}$ Re Canavan (2017) 91 ALJR 1209.

${ }^{3}$ Amy Remeikis, 'Constitutional crisis leaves Turnbull government fighting for its political life', Sydney Morning Herald, 18 August $2017<$ http://www.smh.com.au/federal-politics/political-news/constitutional-crisisleaves-turnbull-government-fighting-for-its-political-life-20170818-gxzi5c.html>.

${ }^{4}$ Mark Kenny, 'Citizenship fiasco deepens, threatening Malcolm Turnbull's authority', Canberra Times, 3 November 2017 <http://www.canberratimes.com.au/federal-politics/political-news/citizenship-fiasco-deepensthreatening-malcolm-turnbulls-authority-20171103-gze314.html>.

${ }^{5}$ George Williams (@ProfGWilliams), "Is this a constitutional crisis? No, I don't think so. This is not anything like the 1975 dismissal. We are experiencing a gigantic constitutional inconvenience.", Twitter, 8 November 2017, 10.15pm <https://twitter.com/ProfGWilliams/status/928506237343350784>.

${ }^{6}$ See House of Representatives Standing Committee on Constitutional and Legal Affairs, Parliament of Australia, Aspects of Section 44 of the Australian Constitution-Subsections 44(i) and (iv) (1997), 10-11; Senate Standing Committee on Constitutional and Legal Affairs, Parliament of Australia, The Constitutional Qualifications of Members of Parliament (1981), 10 [2.14].
} 
In this article, we argue that while the objective of ensuring that parliamentarians are loyal to Australia alone remains defensible, interpretative uncertainties and changing circumstances have turned $\mathrm{s}$ 44(i) into a maladapted mechanism for dealing with parliamentary disqualification. We outline the key problems with s 44(i), argue that the mess is one that Parliament has long been aware of and should have committed to resolve years ago, and explain how that resolution can finally be achieved.

\section{The problems with s 44(i)}

Section 44(i) of the Constitution provides that a person shall be incapable of being chosen for Parliament if he or she: 'is under any acknowledgement of allegiance, obedience or adherence to a foreign power, or is a subject or a citizen or entitled to the rights or privileges of a subject or a citizen of a foreign power'. According to its drafters in the 1890s, the purpose of the section is to protect against split allegiances, and prevent the entry into the Parliament of 'insidious enemies of the Commonwealth', ${ }^{7}$ who may 'get into our Parliament and sell our defence secrets to a foreign power. ${ }^{8}$ Whatever the merits of this objective, $s$ 44(i) has become a poor means of realising it, and is now beset by three key problems.

First, there is a lack of clarity about whether a candidate is disqualified. This uncertainty stems largely from the fact that the High Court has held that the question that must be answered is whether a candidate holds citizenship of a foreign country under the law of that country. ${ }^{9}$ Determining this can require specialist advice from foreign lawyers, and indeed, even when such advice is obtained, the answer is not always clear as foreign citizenship laws can be complex and contentious (especially when English is not the language of legislation and interpretation), and are subject to change. In Re Canavan, for instance, experts in Italian law explained that there is a question whether registering the birth of a person of Italian descent with an Italian consulate is declaratory of the status of citizen or a condition of the grant of the status of citizenship, which must be requested by the applicant. ${ }^{10}$ This issue was material, because while Senator Matt Canavan's birth had been registered, he had not requested a certificate declaration of citizenship. Ultimately, following a joint report of two experts in Italian citizenship that 'suggested' Senator Canavan did not hold Italian citizenship, the Court ruled in his favour. ${ }^{11}$

Additionally, there are questions about the scope of s 44(i) that the High Court has not yet answered, and advice on these matters can therefore only be tentative at best. For example, while the Court has said that a candidate will not be disqualified where they have taken 'all steps that are reasonably required by foreign law' to divest themselves of any foreign citizenship, ${ }^{12}$ when 'all reasonable steps' will be deemed to have been taken remains unclear. Although the forthcoming decision in Re Gallagher ${ }^{13}$ may clarify this, it is unlikely to do so comprehensively, as what constitutes 'reasonable steps' may vary from country to country,

\footnotetext{
${ }^{7}$ Official Record of the Debates of the Australasian Federal Convention, Sydney, 21 September 1897, 1013 (Edmund Barton).

${ }^{8}$ Ibid, 1014 (Simon Fraser).

${ }^{9}$ Re Canavan (2017) 91 ALJR 1209, 1222 [66], 1222-23 [68]-[69]; Sykes v Cleary (1992) 176 CLR 77, 113-114 (Brennan J).

${ }^{10}$ Re Canavan (2017) 91 ALJR 1209, 1224 [83].

${ }^{11}$ Re Canavan (2017) 91 ALJR 1209, 1225 [86].

${ }^{12}$ Re Canavan [2017] 91 ALJR 1209, 1223 [72]. See also Sykes v Cleary (1992) 176 CLR 77, 107 (Mason, Toohey \& McHugh JJ); 113-114 (Brennan J); 131 (Dawson J).

${ }^{13}$ Case C32/2017. See also Transcript of Proceedings, Re Gallagher [2018] HCA Trans 14 (14 March 2018).
} 
and depend on the circumstances of the individual affected. Similarly, the text of s 44(i) says that a candidate will be disqualified where they are 'entitled to the rights or privileges of a subject or citizen of a foreign power'. While the Court has explained that 'entitled' connotes 'a state of affairs involving the existence of a status or of rights under the law of the foreign power', ${ }^{14}$ it is not clear what status or rights will satisfy this standard. It has been suggested that this part of s 44(i) might capture people who do not hold foreign citizenship, but who hold rights or benefits that commonly flow from citizenship, such as possessing a passport, or voting, ${ }^{15}$ particularly where holding these rights signifies a duty of allegiance or obedience to the foreign power. ${ }^{16}$ Indeed, in Re Canavan, when the High Court found that Senator Nick Xenophon was not disqualified under s 44(i), it placed particular reliance on the fact that his status as a British Overseas Citizen did not require him to pledge loyalty to the United Kingdom or entitle him to the right to enter the country. However, whether any foreign status or rights possession gives rise to a 'reciprocal obligation of allegiance' ${ }^{17}$ is a factual matter to be determined in each case.

Uncertainties about the scope and operation of s 44(i) make it difficult, often expensive, and sometimes impossible for even a very diligent candidate to comprehensively assess their potential for disqualification. Prospective candidates who are unable to obtain assurance that they are safe from disqualification under s 44 might therefore choose not to nominate for election. Independent candidates and minor parties face additional barriers, as they are more likely to lack sufficient resources to finance thorough investigation and renunciation processes. ${ }^{18}$ It is undesirable that Australian citizens who satisfy the legislative qualifications for election to Parliament should in effect be disbarred from seeking election because of these hurdles.

Second, s 44(i) also imposes barriers to democratic participation for Australians with a migrant background or other connection to another nation. High rates of immigration to Australia mean that this encompasses many millions of Australians who hold foreign citizenship, with or without their knowledge. The 2016 Census revealed that 26.3 per cent of Australians - some 6,163,667 people-were born overseas. ${ }^{19}$ The number jumps to 49 per cent when it includes people either born overseas or with one or both parents born overseas. ${ }^{20}$ These connections are important because foreign citizenship may be conferred or recognised in several ways, including by descent from a parent, grandparent or great grandparent or through marriage. For example, every person who was a Hungarian citizen or is a descendant of a person who was a Hungarian citizen before 1920 or between 1941 and 1945 and speaks Hungarian, may apply to become a Hungarian citizen even if he or she does not live in Hungary. ${ }^{21}$ Similarly, all persons with an Irish citizen grandparent born in Ireland are eligible for Irish citizenship, ${ }^{22}$ and in some cases, citizenship can even be conferred through a great-

\footnotetext{
${ }^{14}$ Re Canavan (2017) 91 ALJR 1209, 1215 [21]-[23].

${ }^{15}$ See eg Kim Rubenstein, 'Does section 44 affect Jewish MPs?', The Australian Jewish News, 7 September 2017 <https://www.jewishnews.net.au/section-44-affect-jewish-mps/68414>.

${ }^{16}$ See Sykes v Cleary (1992) 176 CLR 77, 110 (Brennan J).

${ }^{17}$ Re Canavan (2017) 91 ALJR 1209, 1231-1232 [131]-[134].

${ }^{18}$ See House of Representatives Standing Committee on Constitutional and Legal Affairs, above n 6, Ch 1.

${ }^{19}$ Australian Bureau of Statistics, 'Census Reveals a Fast Changing, Culturally Diverse Nation' (Media Release, 27 June 2017) <http://www.abs.gov.au/ausstats/abs@.nsf/lookup/Media\%20Release3>.

${ }^{20}$ Ibid.

${ }^{21}$ European Union Democracy Observatory, 'Changes to the Hungarian Citizenship Law, July 2010' $<$ http://cadmus.eui.eu/bitstream/handle/1814/19616/Hungary.pdf>; Act LV of 1993 on Hungarian Citizenship (15 June 1993).

${ }^{22}$ Irish Nationality and Citizenship Act 1956 (Ire) s 7.
} 
grandparent. ${ }^{23}$ Citizenship by descent is also sometimes conferred automatically, such that a person may possess foreign citizenship without seeking it or knowing about it. For example, Norway confers citizenship upon any child born anywhere in the world to a Norwegian citizen. $^{24}$

Citizenship can also be automatically conferred by marriage. For instance, foreign women who married an Italian citizen before 27 April 1983 were automatically granted Italian citizenship. $^{25}$ Newspaper reports suggest that Nola Marino, MP for Forrest, may have acquired Italian citizenship through marriage in this manner. ${ }^{26}$ In her Statement lodged on the Citizenship Register, however, Ms Marino declared that she had sought legal advice and is assured that she is not an Italian citizen, though she has not provided that advice. ${ }^{27}$

Furthermore, it is common for the eligibility requirements for citizenship in foreign countries to change from time to time (as they have in Australia). There is thus uncertainty about which individuals hold dual citizenship at any given point. Former Greens senator Larissa Waters, who was born in Canada to Australian parents but migrated to Australia at the age of 11 months, was disqualified under s 44(i) because she was granted Canadian citizenship at birth under the legislation in force at the time. ${ }^{28} \mathrm{Had}$ Ms Waters been born a mere week later, she would never have been granted Canadian citizenship and thus would not have been disqualified, due to the introduction of new Canadian legislation. ${ }^{29}$

We suggest that in a country with Australia's high rates of immigration and ethnic diversity, citizens should not be barred from democratic participation in federal Parliament on account of foreign connections as weak as those described above.

Third, the uncertainties that arise under s 44(i) can threaten the integrity and stability of Parliament. ${ }^{30}$ The lack of understanding around what s 44 requires creates a risk that candidates who fall foul of the disqualification criteria but who do not realise this will stand for election, and in some cases will be elected. In situations like the present, where a large number of parliamentarians have had their eligibility questioned and have had to resign, the legitimacy of the entire Parliament can be called into question. Indeed, a fresh election has not infrequently been suggested as a definitive action to resolve these issues. ${ }^{31}$ The stability of Parliament and integrity of government is particularly pronounced in the current

\footnotetext{
${ }^{23}$ This occurs where a person's parents were registered on the Irish Foreign Births Register: Irish Nationality and Citizenship Act 1956 (Ire) s 27

24 'Norwegian by Birth?', Norwegian Directorate of Immigration (Web Page) https://www.udi.no/en/worddefinitions/norwegian-by-birth/>. In some, but not all, cases Norwegian citizenship is lost at the age of 22 where foreign citizenship is held and no application to retain it is lodged.

${ }^{25}$ Law No. 555 of 13 June 1912 (Italy) as amended by Law No. 123 of 21 April 1983 (Italy).

${ }^{26}$ Adam Gartrell and Eryk Bagshaw, 'Citizenship Crisis: Turnbull Government MP Nola Marino may be an Italian Citizen by Marriage’, Sydney Morning Herald, 10 November 2017 <http://www.smh.com.au/federalpolitics/political-news/citizenship-crisis-turnbull-government-mp-nola-marino-may-be-an-italian-citizen-bymarriage-20171109-gzig4g.html>.

${ }^{27}$ Ms Nola Marino MP, 'Statement in Relation to Citizenship-45 Citizenship Register (5 December 2017) 3.

${ }^{28}$ Canadian Citizenship Act, RSC 1970, c C-19, s 5(a).

${ }^{29}$ Citizenship Act, SC 1974-75-76, c 108, s 3(1)(a). Ms Waters retained her Canadian citizenship pursuant to s $3(1)(d)$ of this Act.

${ }^{30}$ Ibid., 37, 57-8.

${ }^{31}$ Michelle Grattan, 'Grattan on Friday: Voters just want citizenship crisis fixed — but it isn't that easy', The Conversation, 9 November 2017 <https://theconversation.com/grattan-on-friday-voters-just-want-citizenshipcrisis-fixed-but-it-isnt-that-easy-87201>
} 
Parliament, where the government has a one-seat majority in the House of Representatives. As was noted prior to the by-elections in New England and Bennelong, a by-election in a government-held seat could trigger a change in parliamentary support, a successful noconfidence motion, and an early election.

Additionally, ineligible candidates who run for the House of Representatives have the potential to alter election results, even where the ineligible candidates are not themselves elected. This is because many candidates are elected due to preference flows. This creates an additional risk: where an unsuccessful candidate is found to be ineligible because of s 44, their disqualification might be used to challenge the eligibility of a parliamentarian whose election hinged upon the disqualified candidate's preference flows. While cases disputing elections must be commenced within 40 days of polling, ${ }^{32}$ this places a question mark, at least for a period, over the eligibility of many federal parliamentarians, even those whose compliance with s 44 is not in any doubt. ${ }^{33}$

\section{A known problem}

A concerning aspect of the current crisis is that it was so predictable. While s 44(i) has only recently attained popular attention, it has intermittently been used to challenge the eligibility of members since 1904, and parliamentarians have long recognised that s 44(i) might wreak havoc. As Table 1 illustrates, the current citizenship crisis should not have taken Parliament by surprise: while it was not until 1999 that a member of Parliament was ruled ineligible under s 44(i), a number of cases in recent years has suggested that dual allegiance may render a person ineligible.

Table 1: Section 44(i) cases

\begin{tabular}{|l|l|l|l|l|l|}
\hline Year & Name & Party & Allegation & Case & Result \\
\hline 1904 & $\begin{array}{l}\text { Malcolm } \\
\text { McEacharn }\end{array}$ & Independent & $\begin{array}{l}\text { As Honorary Consul for } \\
\text { Japan was under an } \\
\text { allegiance, obedience or } \\
\text { adherence to a foreign } \\
\text { power }\end{array}$ & $\begin{array}{l}\text { Maloney } v \\
\text { McEacharn } \\
\text { (1904) 1 CLR 77 }\end{array}$ & $\begin{array}{l}\text { s 44(i) not } \\
\text { addressed in } \\
\text { decision, } \\
\text { petition upheld } \\
\text { on ballot } \\
\text { irregularities }\end{array}$ \\
\hline 1946 & $\begin{array}{l}\text { William } \\
\text { O'Connor }\end{array}$ & ALP & $\begin{array}{l}\text { As a Roman Catholic } \\
\text { owed allegiance to a } \\
\text { foreign power }\end{array}$ & $\begin{array}{l}\text { Petition } \\
\text { withdrawn }\end{array}$ \\
\hline 1950 & Gordon Anderson & ALP & $\begin{array}{l}\text { As a Roman Catholic } \\
\text { owed allegiance to a } \\
\text { foreign power }\end{array}$ & $\begin{array}{l}\text { Crittenden v } \\
\text { Anderson (1950) } \\
51 \text { ALJ 171 }\end{array}$ & Dismissed \\
\hline 1987 & Robert Wood & $\begin{array}{l}\text { Nuclear } \\
\text { Disarmament } \\
\text { Party }\end{array}$ & $\begin{array}{l}\text { Wood paddled a kayak in } \\
\text { front of US warship; } \\
\text { alleged that his actions } \\
\text { against vessels of a } \\
\text { friendly nation indicate }\end{array}$ & $\begin{array}{l}\text { Nile v Wood } \\
(1987) \text { 167 CLR } \\
133\end{array}$ & Dismissed \\
\hline
\end{tabular}

${ }^{32}$ Commonwealth Electoral Act 1918 (Cth) s 355.

${ }^{33}$ See further Evidence to Joint Standing Committee on Electoral Matters, Parliament of Australia, Canberra, 8 December 2017, 24-5, 26-7 (George Williams); Evidence to Joint Standing Committee on Electoral Matters, Parliament of Australia, Melbourne, 1 February 2018, 15, 17-18 (Luke Beck); Luke Beck, Submission to the Joint Standing Committee on Electoral Matters Inquiry into Matters Relating to Section 44 of the Constitution (January 2018), 2. 


\begin{tabular}{|c|c|c|c|c|c|}
\hline & & & $\begin{array}{l}\text { allegiance, obedience or } \\
\text { adherence to a foreign } \\
\text { power }\end{array}$ & & \\
\hline 1992 & Bill Kardamitsis & ALP & $\begin{array}{l}\text { (i) Greek dual citizen - } \\
\text { had not taken reasonable } \\
\text { steps to renounce dual } \\
\text { citizenship } \\
\text { (ii) Position as 'officer' of } \\
\text { Greek Orthodox Church } \\
\text { amounted to allegiance in } \\
\text { breach of s 44(i) }\end{array}$ & $\begin{array}{l}\text { Skyes v Cleary } \\
(1992) 176 \text { CLR } \\
77\end{array}$ & $\begin{array}{l}\text { Kardamitsis } \\
\text { declared } \\
\text { ineligible on } \\
\text { (i); (ii) struck } \\
\text { out in } \\
\text { directions } \\
\text { hearing }\end{array}$ \\
\hline 1992 & John Delacretaz & Liberal & $\begin{array}{l}\text { Swiss dual citizen }- \text { had } \\
\text { not taken reasonable steps } \\
\text { to renounce dual } \\
\text { citizenship }\end{array}$ & $\begin{array}{l}\text { Skyes v Cleary } \\
(1992) 176 \text { CLR } \\
77\end{array}$ & $\begin{array}{l}\text { Delacretaz } \\
\text { declared } \\
\text { ineligible }\end{array}$ \\
\hline 1996 & Jackie Kelly & Liberal & Dual NZ citizen & $\begin{array}{l}\text { Free v Kelly } \\
\text { (1996) } 185 \text { CLR } \\
296\end{array}$ & $\begin{array}{l}\text { s 44(i) not } \\
\text { pursued, } \\
\text { declared } \\
\text { ineligible } \\
\text { under s 44(iv) }\end{array}$ \\
\hline 1998 & Heather Hill & One Nation & Dual UK citizen & $\begin{array}{l}\text { Sue v Hill (1999) } \\
199 \text { CLR } 462\end{array}$ & $\begin{array}{l}\text { Declared } \\
\text { ineligible }\end{array}$ \\
\hline 2017 & Lucy Gichuhi & Family First & Dual Kenyan citizen & $\begin{array}{l}\text { Transcript of } \\
\text { Proceedings, Re } \\
\text { Day [2017] } \\
\text { HCATrans } 86 \\
\text { (19 April 2017) }\end{array}$ & $\begin{array}{l}\text { Petition } \\
\text { dismissed for } \\
\text { delay }\end{array}$ \\
\hline 2017 & Scott Ludlam & Greens & Dual NZ citizen & $\begin{array}{l}\text { Re Canavan } \\
\text { [2017] HCA 45 }\end{array}$ & Resigned \\
\hline 2017 & Larissa Waters & Greens & Dual Canadian citizen & $\begin{array}{l}\text { Re Canavan } \\
\text { [2017] HCA } 45\end{array}$ & Resigned \\
\hline 2017 & Matt Canavan & National & Dual Italian citizen & $\begin{array}{l}\text { Re Canavan } \\
\text { [2017] HCA } 45\end{array}$ & Dismissed \\
\hline 2017 & Barnaby Joyce & National & Dual NZ citizen & $\begin{array}{l}\text { Re Canavan } \\
\text { [2017] HCA } 45\end{array}$ & $\begin{array}{l}\text { Declared } \\
\text { ineligible }\end{array}$ \\
\hline 2017 & Fiona Nash & National & Dual UK citizen; & $\begin{array}{l}\text { Re Canavan } \\
\text { [2017] HCA } 45\end{array}$ & $\begin{array}{l}\text { Declared } \\
\text { ineligible }\end{array}$ \\
\hline 2017 & Nick Xenophon & NXT & Dual UK Overseas citizen & $\begin{array}{l}\text { Re Canavan } \\
\text { [2017] HCA } 45\end{array}$ & Dismissed \\
\hline 2017 & Malcolm Roberts & One Nation & Dual UK citizen & $\begin{array}{l}\text { Re Canavan } \\
\text { [2017] HCA } 45\end{array}$ & $\begin{array}{l}\text { Declared } \\
\text { ineligible }\end{array}$ \\
\hline 2017 & Jackie Lambie & JLN & Dual UK citizen & - & Resigned \\
\hline 2017 & John Alexander & Liberal & Dual UK citizen & - & Resigned \\
\hline 2017 & Stephen Parry & Liberal & Dual UK citizen & - & Resigned \\
\hline 2018 & David Feeney & ALP & Dual UK citizen & - & Resigned \\
\hline 2018 & $\begin{array}{l}\text { Skye Kakoschke- } \\
\text { Moore }\end{array}$ & NXT & $\begin{array}{l}\text { Kakoschke-Moore } \\
\text { resigned and then } \\
\text { renounced her dual } \\
\text { citizenship prior to next }\end{array}$ & $\begin{array}{l}\text { Re Kakoschke- } \\
\text { Moore C30/2017 }\end{array}$ & $\begin{array}{l}\text { Declared } \\
\text { ineligible }\end{array}$ \\
\hline
\end{tabular}




\begin{tabular}{|l|l|l|l|l|l|}
\hline & & $\begin{array}{l}\text { candidate chosen; argued } \\
\text { that disqualification } \\
\text { removed by that time and } \\
\text { should be re-appointed by } \\
\text { HCA. }\end{array}$ & \\
\hline 2018 & Katy Gallagher & ALP & $\begin{array}{l}\text { Potentially a dual UK } \\
\text { citizen }\end{array}$ & $\begin{array}{l}\text { Re Gallagher } \\
\text { C32/2017 }\end{array}$ & $\begin{array}{l}\text { Decision } \\
\text { forthcoming at } \\
\text { time of writing }\end{array}$ \\
\hline
\end{tabular}

Many parliamentarians have clearly been aware that 's 44(i) lies in wait'. ${ }^{34}$ In 1998 , for instance, Senator Nick Sherry commented on allegations that Senator-elect Heather Hill was a dual UK citizen. Senator Sherry noted that the High Court's 1992 decision in Sykes $v$ Cleary, where the Court held that both the Labor and Liberal candidates had not taken all reasonable steps to renounce their dual citizenship and were therefore ineligible under s 44(i), had sparked a panic among parliamentarians.

It is fair to say that at the end of 1992 this did cause some major concerns for members of parliament. I was one of them. I do not recall the exact number, but there were certainly double figures of members of the House of Representatives and the Senate for whom there was an arguable case over whether they had failed to renounce the country of their home of birth. If there was a formal procedure, even if they had Australia citizenship, as a consequence of the High Court decision they were open to challenge-let us put it that way. I was one of those who, in a flurry of activity, dashed down to the British High Commission, sought out the details for renunciation of citizenship from Britain, paid the appropriate fee-which at that time was $\$ 50$, I think - and lodged renunciation forms. There were quite a number of members of parliament at that time who had to go through that procedure. ${ }^{35}$

It is not only individual parliamentarians who have been aware. Parliament has repeatedly identified that s 44(i) could render large numbers of parliamentarians ineligible. In 1981, the Senate Legal and Constitutional Affairs Committee warned that it was 'most invidious' to deny Australians with 'unsought dual nationality' the right to serve in Parliament. ${ }^{36}$ In 1989 , following the Re Wood case, the Parliamentary Library released an extensive report exploring s 44(i), concluding that the provision 'poses a problem which goes right to the heart of a representative democracy'. ${ }^{37}$ In 1992, after the Sykes $v$ Cleary decision, a substantially revised version of the report was published. The revised report noted that while it is unclear when the United Kingdom became a foreign power, it certainly was one at present, anticipating the issue in Sue $v$ Hill by several years. ${ }^{38}$

In 1997 the House of Representatives Standing Committee on Legal and Constitutional Affairs convened a report into Aspects of $s 44$ of the Australian Constitution. This was a response to earlier suggestions that many representatives might be disqualified. The

\footnotetext{
${ }^{34}$ Damien Cremean, 'Parliamentary Disqualification' (2011) 19 Australian Journal of Administrative Law 3, 4.

${ }^{35}$ Commonwealth, Parliamentary Debates, Senate, 25 November 1998, 616.

${ }^{36}$ Senate Standing Committee on Constitutional and Legal Affairs, above n 6, [2.18].

${ }^{37}$ Sarah O'Brien, Membership of the Parliament: A Review of s 44(i) of the Constitution (Parliamentary Library, 11 May 1989) 48.

${ }^{38}$ Sarah O’Brien, Dual Citizenship, Foreign Allegiance and s 44(i) of the Australian Constitution

(Parliamentary Library, 9 December 1992) Attachment B.
} 
committee recognised this in saying, 'It is possible that there will be an increasing number of challenges under the provision ... After one election 35 members of parliament, and after another election 57 members, were alleged to be disqualified. ${ }^{39}$ It warned that:

One complication caused by the ways dual citizenship can be acquired is that there are probably many Australian born citizens who are not aware that they are, or are eligible to be, dual nationals ... [At] some time in the future a parliamentarian could declare that he or she is unaware that he or she is a dual citizen and therefore does not know that there is any other citizenship to renounce. ${ }^{40}$

The committee concluded that section 44 could lead to chaos:

The Committee considers that the potential exists for challenges to the eligibility of a significant number of parliamentarians especially in view of the fact that a large number of Australian citizens possess dual citizenship. This represents a risk to the integrity and stability of the parliamentary system and to the government of the nation.

For example, it is not difficult to envisage a situation where, following an election, the balance between the major political parties, or coalitions of parties, in the House of Representatives was fairly even and where challenges to five or six elected representatives could throw into doubt the outcome of the whole election. It could make government virtually impossible since neither political grouping could take office confident of majority support. In those circumstances, it could take months for High Court challenges to be resolved and for by-elections to occur. ${ }^{41}$

This was the prediction Parliament itself made 21 years ago.

\section{How can we resolve this mess?}

Three resolution options are on the table: legislative reform, administrative reform and constitutional reform. We suggest that, while legislative and administrative changes might appear to be quicker fixes to the problems posed by s 44(i), only constitutional reform is capable of providing a durable solution.

The fundamental problems with s 44(i) cannot be resolved by legislative reform. ${ }^{42}$ Parliament cannot legislate to alter the disqualification criteria to improve certainty and predictability because the interpretation of s 44(i) is a task for the High Court, and the Court has made it clear that compliance depends upon the operation of foreign citizenship laws. This means that Parliament cannot pass a law providing a standard procedure (such as a unilateral declaration of renunciation in the oath of allegiance sworn by all members of Parliament) for divesting

\footnotetext{
${ }^{39}$ House of Representatives Standing Committee on Constitutional and Legal Affairs, above n 6, 12 [2.7].

${ }^{40}$ Ibid, 22 [2.31].

${ }^{41}$ Ibid, 37 [2.72].

42 This is in line with the weight of evidence presented to the House of Representatives Standing Committee on Constitutional and Legal Affairs during its 1997 inquiry into ss 44(i) and (iv): Ibid, 50.
} 
oneself of any foreign citizenship. ${ }^{43}$ Similarly, Parliament also lacks the constitutional power to pass legislation that dictates what would constitute 'reasonable steps' to divest oneself of foreign citizenship. This is a question pertaining to the interpretation of s 44(i) and can only be answered by the High Court. ${ }^{44}$

Parliament is able to alter the procedures for challenging a parliamentarian's qualifications. Section 47 of the Constitution provides that until Parliament otherwise provides:

any question respecting the qualification of a Senator or a Member of the House of Representatives, or respecting a vacancy in either house of the Parliament...shall be determined by the House in which the question arises.

Under s 376 of the Commonwealth Electoral Act 1918 (Cth), the Parliament conferred jurisdiction to deal with these issues on the Court of Disputed Returns, upon a referral by the house in which the question arises. Parliament could amend this Act to alter the procedure for referring candidates to the High Court, or even to remove this procedure altogether to enable itself to resolve all such matters by way of a vote on the floor of Parliament. Indeed, in the recent case of Alley $v$ Gillespie, ${ }^{45}$ the High Court affirmed that unless and until Parliament chooses to refer a matter to the Court of Disputed Returns, questions about whether particular members are incapable of sitting in Parliament are a matter for Parliament itself. ${ }^{46}$ However, this is an undesirable fix: such a partisan process would not restore public confidence nor ensure that every member of the federal Parliament is entitled to remain in their seat.

Because of the uncertainties about what is required to comply with s 44(i), administrative measures also cannot provide a complete resolution to the difficulties that arise out of the provision. Measures such as a comprehensive pre-nomination questionnaire, audit processes, or services to assist candidates with the renunciation of foreign citizenship, can assist candidates to comply with the aspects of s 44(i) that are clear, but they cannot create clarity about the constitutional rules where this does not exist. Nonetheless, improvements to administrative processes can provide important supplementary assistance in the immediate term to help restore public confidence.

In December 2017, a Citizenship Register was established. The Register requires Senators and Members of the House of Representatives to declare information that might help reveal circumstances in which a referral under s 44(i) is warranted. This is a useful device to promote transparency and help restore public confidence in the immediate term. However, several improvements are required before the Register can serve this purpose effectively. For

\footnotetext{
${ }^{43}$ In Sykes v Cleary (1992) 176 CLR 77, Gaudron J suggested that the Commonwealth Parliament could legislate to provide that a person may renounce their foreign citizenship in compliance with Australian law, and that the Court should not apply the law of the foreign country in determining questions under s 44(i) (at 137). The High Court ruled out this possibility in Re Canavan (2017) 91 ALJR 1209, 1218 [37].

44 Though cf. Lael K Weis, 'Legislation as a Method of Constitutional Reform: An Alternative to Formal Amendment?' on AUSPUBLAW (26 March 2018) <https://auspublaw.org/2018/03/legislation-as-a-method-ofconstitutional-reform/>.

45 [2018] HCA 11.

46 The central issue in the case was whether if, in the absence of a parliamentary reference, an individual commences action in the High Court against a member of Parliament under s 3(1) of the Common Informers (Parliamentary Disqualifications) Act 1975 (Cth), the High Court can determine whether the member is incapable of sitting as a member of Parliament. All judges held that the Court does not have such jurisdiction: see Alley v Gillespie [2018] HCA 11, [9]-[13], [67] (Kiefel CJ, Bell, Keane and Edelman JJ), [70] (Gageler J), [90] (Nettle and Gordon JJ).
} 
example, parliamentarians are currently required to disclose the place and date of their birth and any citizenship they held at that time. They are also required to disclose 'so far as the Member is aware' the place and date of the birth of the Member's parents, grandparents and spouse. They are not however, required to disclose the citizenship of their parents, grandparents or spouses. In addition, the declarations lack a supporting process, with no mandated consequences for parliamentarians who fail to provide documentary evidence, or who have provided declarations without having taken reasonable steps to check if they are a foreign citizen. ${ }^{47}$

As legislative and administrative measures cannot resolve the problems that surround s 44(i), the only effective long-term solution is to change the terms of $\mathrm{s} 44$ itself-a solution repeatedly identified by the Parliament. ${ }^{48}$ This would require, in accordance with s 128 of the Constitution, a referendum of the Australian people. There are two main ways in which constitutional reform could be approached: s 44 (and associated provisions) could be amended to modernise and clarify the grounds for disqualification; or the section could be changed to grant Parliament the power to determine the criteria for disqualification through legislation.

Under the first option, there are a number of ways in which s 44(i) might be reformed. It would, for instance, be an option to amend s 44(i) to more clearly define the circumstances in which a dual citizen would be ineligible to stand for Parliament. Examples of this can be found in the constitutions of New South Wales, ${ }^{49}$ South Australia, ${ }^{50}$ Tasmania, ${ }^{51}$ and New Zealand. ${ }^{52}$ In each of these jurisdictions, dual citizens may generally serve as Members of Parliament, and are only disqualified if they actively take up foreign citizenship, or act on a right from their foreign citizenship held prior to their election, such as obtaining a passport, while a member. Alternatively, it would be an option to remove s 44(i) entirely, eliminating any constitutional barrier to dual citizens serving in the Commonwealth Parliament. This would mirror the position in Victoria, ${ }^{53}$ Western Australia, ${ }^{54}$ Queensland, ${ }^{55}$ the ACT, ${ }^{56}$ and the Northern Territory, ${ }^{57}$ as well as the United Kingdom, ${ }^{58}$ and the United States Congress. ${ }^{59}$

The second option is preferable. It is in line with how the Constitution currently determines a number of related matters, including voter eligibility (s 30), and the qualifications of

\footnotetext{
${ }^{47}$ Parliament of Australia, Members' statements in relation to citizenship, Resolution adopted 4 December 2017, (1).

${ }^{48}$ Senate Standing Committee on Constitutional and Legal Affairs, above n 6, Recommendation 3; House of Representatives Standing Committee on Constitutional and Legal Affairs, above n 6, Recommendation 2. See also the 1988 Constitutional Commission: Commonwealth, Final Report of the Constitutional Commission 1988 (1988) [4.735];

${ }^{49}$ Constitution Act 1902 (NSW), s 13A(b)

${ }^{50}$ Constitution Act 1934 (SA), s 17(1) (b)-(c).

${ }^{51}$ Constitution Act 1934 (Tas), s 34(b)-(c).

${ }^{52}$ Electoral Act 1993 (NZ) ss 55(1)(b)-(c), (2), 55AA(a)-(b). See further Jeremy Waldron, 'How Dodgy Was Duynhoven?' (2004) 10 Otago Law Review 631.

${ }^{53}$ No bar on dual citizens is provided in the Constitution Act 1975 (Vic) ss 44-66A.

${ }^{54}$ No bar on dual citizens is provided in the Electoral Act 1907 (WA) and Constitution Acts Amendment Act 1899 (WA).

${ }^{55}$ No bar on dual citizens is provided in the Electoral Act 1992 (Qld) and Constitution of Queensland Act 2011 (Qld).

${ }^{56}$ No bar on dual citizens is provided in the Electoral Act 1992 (ACT) and Australian Capital Territory (SelfGovernment) Act 1988 (ACT)

${ }^{57}$ No bar on dual citizens is provided in the Northern Territory (Self-Government) Act 1978 (Cth) ss 20-21.

${ }^{58} \mathrm{No}$ bar on dual citizens is provided in the Electoral Administration Act 2006 (UK) c 22, Pt 5.

${ }^{59}$ United States Constitution, Art I, s 2; Powell v McCormack, 395 US 486 (1969).
} 
members of parliament (ss 16, 34). The simplest way to grant Parliament such legislative power is to adopt the approach used in ss 30 and 34, by inserting the words 'until the Parliament otherwise provides' at the beginning of $s$ 44. This would leave the existing disqualification criteria in place, as a transitional measure, but would enable Parliament to alter these criteria as required through the passage of legislation. Moreover, it has the advantage of allowing the criteria for parliamentarians to evolve over time in response to changing circumstances and community standards. This would help to guard against any repeat of the current predicament years into the future. Indeed, during the lead-up to Federation, Patrick Glynn proposed this very approach, though his proposal did not win favour. ${ }^{60}$

This approach adopts a constitutional formula that has been used, without issue, in related contexts. It would also allow Parliament freedom to amend the disqualification criteria as needed, while leaving a constitutional standard in place where no changes have been made. It thus offers a durable solution by enabling the criteria to be progressively updated to reflect changing community standards or practical realities, and it forces Parliament to justify why change is needed when any such updates are proposed.

Before a referendum question is put to the Australian people, its prospects of success should be carefully considered. We suggest that any proposed change to s 44(i) should be put to the Australian people at the next general election. This would allow adequate time to build a public case for change and would be significantly cheaper than a standalone referendum. Indeed, the Australian Electoral Commission told a parliamentary inquiry in 2015 that a standalone referendum would cost $\$ 158.4$ million but holding a referendum on the same day as a general election would cost $\$ 44$ million. $^{61}$

\section{Conclusion}

The uncertainties that arise under s 44(i) impose large and distorting costs on Australian democracy and threaten the integrity of the Parliament. Parliament has repeatedly identified that the only effective way to resolve these problems is via a referendum. It is beyond time to hold this referendum. The citizenship crisis that has plagued the current Parliament should serve as the catalyst for lasting change that enables the rules for disqualification to be set by Parliament itself. This should be put to the people at a referendum held at the next general election.

Harry Hobbs is a PhD candidate, Lionel Murphy Postgraduate Scholar, and Garth Nettheim Doctoral Teaching Fellow at UNSW Law.

Sangeetha Pillai is a Senior Research Associate at the Andrew \& Renata Kaldor Centre for International Refugee Law, at UNSW Law.

George Williams is the Dean, Anthony Mason Professor and Scientia Professor, UNSW Law

\footnotetext{
${ }^{60}$ Official Record of the Debates of the Australasian Federal Convention, Sydney, 21 September 1897, 1013.

${ }^{61}$ Australian Electoral Commissioner, Submission No 26 to the Senate Legal and Constitutional Affairs

Committee, Inquiry into the Matter of a Popular Vote, in the form of a Plebiscite or Referendum, on the Matter of Marriage in Australia (4 September 2015) 10.
} 
This article is based on their joint submission to the Joint Standing Committee on Electoral Matters inquiry into matters relating to Section 44 of the Constitution. 